\title{
FUNDING OF MUNICIPALITIES IN SLOVAK REPUBLIC, RELATED APPLICATION PROBLEMS AND FUTURE CHALLENGES ${ }^{1}$
}

\begin{abstract}
Authors to the chapter provide for the picture of revenue sources of municipalities in Slovakia with an emphasize on local taxes as one source of their revenues and subsequently deal with particular application problems thereto related. Due to the European Charter of Local Self-Government, local authorities shall be entitled, within national economic policy, to adequate financial resources of their own of which they may dispose freely within the framework of their powers. A relatively wide degree of autonomy of local taxes administrators in Slovak Republic, especially as regards the authority to decide on tax rates, represents a source of application problems. Authors will analyse the above mentioned issues in order to evaluate the overall situation and confirm or disprove the hypothesis that (a) current own revenue resources of local self-government are insufficient and systematic changes need to be made and (b) providing the local self-government with autonomy regarding determination of their revenue sources and/or some aspects of their legislation is necessary however capable of being misused and/or misconducted. Especially the methods of analysis, synthesis, comparison and historical methods will be applied.
\end{abstract}

Keywords: municipality; self-government; budget; revenue local taxes; real estate tax; autonomy; tax administration.

1 The paper represents a partial output from the implementation of project VEGA No. $1 / 0375 / 15$ "Tax evasion and tax frauds and possibilities of their prevention (by means of tax law, commercial law and criminal law)". 


\section{Introduction}

The Constitutional Act no. 460/1992 Coll. the Constitution of Slovak Republic (hereinafter referred to as the "Constitution") stipulates in art. 64 that the basis of local self-government is a municipality; and that local self-government is created by municipalities and higher territorial units. For the purpose of this chapter, we will analyse the situation and legislation concerning municipalities only. Among the most important issues regarding the life of local self-government, it sets forth also the issue of their funding. The basic characteristic of local government includes the ability to fulfil its financial resourc$\mathrm{es}^{2}$. Slovak Republic ratified The European Charter of Local Self-Government (hereinafter referred to as the "Charter") to establish mechanisms which would ensure the financial stability of municipalities and higher territorial units. Complete ratification of the Charter was realized in 2007. The Charter defines local government as the right and the ability of local authorities, within the limits of the law, to regulate and manage a substantial share of public affairs under their own responsibility and in the interests of the local population. ${ }^{3}$ Budgetary issues of local self-government are regulated mainly by art. 9 of the Charter - Financial resources of local authorities. The main idea of that provision is expressed, within national economic policy, in the right on adequate own financial resources, of which they may dispose freely within the framework of their powers. Local authorities' financial resources shall be proportional to the responsibilities granted by the Constitution and the laws. The Charter assumes that at least a part of the financial resources of local authorities shall be derived from local taxes and charges and that the authority of determination of their rates will, within the statutory limits, belong to the municipalities. ${ }^{4}$ Nevertheless, the art. 9 par. 4 of the Charter declares that the financial systems on which the resources available to local authorities are based shall be of a sufficiently diversified and buoyant nature to enable them, as far as practically possible, to keep pace with the real evolution of the cost of carrying out their tasks.

Following this, the Act no. 369/1990 Coll. on municipalities (hereinafter referred to as the "Act on Municipalities") confirms this "own revenue" principle in its art. 7 and sets further fort also other resources, such as repayable funding

2 Art. 65 par. 2 of the Constitution declares that municipalities shall fund their needs predominantly with the use of their own revenues, and subsequently from state grants.

3 The European Charter of Local Self-Government, art. 3 section 1.

4 Compare: art. 9 section 3 The European Charter of Self-Government. 
sources, extra-budgetary cash funds or funds associated with other municipalities, higher territorial units, and natural or legal persons. The Act no. 583/2004 Coll. on fiscal rules of local self-government and on change and amendment of certain laws (hereinafter referred to as the "Act on Fiscal Rules") sets forth that revenues of municipalities' budgets consist of own resources and other resourc$\mathrm{es}^{5}$. Own resources are created by revenues of local taxes and charges, non-tax revenues from the ownership and transfer of ownership of municipal property and activities of the municipality and its budgetary organizations, interest and other revenues from the funds of the municipality, sanctions for violations of financial discipline imposed by the municipality, donations and revenues from voluntary collections to the municipality, the share of the taxes administered by the state, other revenues on condition that a special law provides so expressly. The others are subsidies from the state budget covering the costs of transferred performance of state administration and subsidies from state funds, additional subsidies from the state budget, purpose-built subsidies from the higher territorial unit or from the budget of another municipality to carry out contracts under special laws (e.g. cooperation between municipalities), funds from the EU and other foreign funds granted for a specific purpose, and other revenues. The municipality is also allowed to use extra-budgetary monetary funds, funds obtained from own business activities, refundable sources of financing, and joint financial resources. The difference consists in the fact that own resources (except for donations for a designated purposes) may be used by a municipality according to its will and needs and the others have to be used only for specified purpose. This structure shows that local self-government has financial relationships to three main groups of persons, i.e. the state/EU and its budget (shared taxes, subsides), other municipalities and higher territorial units, (subsidies, joint resources) and the third one being other natural and legal persons (mainly taxpayers, banks and other financial institutions, business partners, tenants, buyers of municipal property, donators, etc.).

\section{Current most relevant municipal resources}

As we already mentioned, system of local revenues is quite comprehensive, yet, there are some groups of resources that might be pointed out as most relevant (from the budgetary point of view.).

5 Art. 3 para. $1-3$ of the Act on Fiscal Rules. 
Act no. 564/2004 Coll. on budgetary determination of income tax revenue for local self-governments and amending certain laws is the basis of sharing the revenue of personal income tax (excluding withholding taxes) as a state tax among municipalities and higher territorial units. For current budgetary year, i.e. 2016, the revenue from the income tax to be transferred ${ }^{6}$ to municipal budgets is in the amount of $70.0 \%$ (and to budgets of higher territorial units in the amount of $30.0 \%){ }^{7}$ The sums are the distributed to particular municipalities pursuant to specific criteria defined by the Government regulation no. 668/2004 Coll. on distribution of personal income tax revenue to local self-government (comprising data on number and structure of residents, area, and other coefficients).

Subsidies granted to municipalities come from three sources: Firstly, there are subsidies from the state budget covering the costs of transferred performance of state administration and subsidies from state funds. Subsidies from the state budget are granted following the details of the state budget for particular budget year and are granted from budget chapters of particular ministry, e.g. ministry of the interior: regarding operating of the registry offices, reporting of residence of citizens and operating registry of inhabitants of the Slovak Republic, the elections, funding of regional education, etc.; ministry of transport, construction and regional development: tasks of specialised building office, etc.. Secondly, additional subsidies from the state budget (for specific purposes) may be granted. As regards these purpose-built subsidies, these cover usually issues of housing development, support of territorial development of cities and municipalities, funding individual needs of municipalities, protection and restoration of cultural heritage, regional development, or special tasks such as protection and maintenance of the war graves. Thirdly, purpose-built subsidies may be granted from the higher territorial unit or from the budget of another municipality to carry out contracts under special laws (e.g. cooperation between municipalities ${ }^{8}$ ). Municipalities may, under art. 7 para. 2 of the Act on Fiscal Rules, provide grants to another municipality or higher territorial unit

6 Which meant e.g. for the year 2014 EUR 1727060 000. Available at the Internet: file://C:/ Users/AK/Downloads/prevod_vynosu_dane_z_prijmov_FO_uzemnej_samosprave_za_ rok_2014.pdf.

7 In comparison to the previous year, the amount has been raised from $68.5 \%$ for the municipalities and from $29.2 \%$ for the higher territorial units.

8 For details see: A. Kicová, M. Štrkolec, Vzájomné finančno-právne vzt’ahy jednotiek územnej samosprávy, [in:] Finanse samorzadu terytorialnego, Radom 2012, pp. 381-391. 
if they secure certain tasks for the municipality or for assistance in liquidation of consequences of natural disasters, accidents or other similar events in their area. Likewise, higher territorial unit may, under art. 8 para. 4 of the Act on Fiscal Rules, provide grants to municipalities on its territory as for participation in the funding of common tasks in order to develop the area of higher territorial unit and also to other municipalities or higher territorial units, if it is to provide assistance in liquidation of consequences of natural disasters, accidents or other similar events in their area. The use of subsidies must comply with the purpose for which they were granted and is subject to settlement with the state budget. Unused funds or those used in breach of purpose or other conditions upon which the subsidy was granted must be returned to the provider of subsidy. The Act on Municipalities provides municipalities with a possibility to fund their tasks by the resources associated with other municipalities, higher territorial units or with other natural and legal persons. Municipalities may establish a joint extra-budgetary cash funds for funding of the tasks common to more municipalities or for any other reason. Most common reasons are joint exercise of responsibilities in the area of technical infrastructure, the environment, economic development, administration, applying for grants from the European funds for development projects, development of culture, tourism, sport, etc. Administration of such a fund is then performed by a board established by the founding municipalities according to mutually agreed rules.

As regards local taxes, these are regulated and were introduced by the act of 23 September 2004 no. 582/2004 Coll. on local taxes and local charge for municipal waste and minor construction waste (hereinafter only "Act on Local Taxes") abolishing the former regulation of act no. 317/1992 Coll. on real property tax, act no. 544/1990 Coll. on local charges and act no. 87/1994 Coll. on road tax. The Act on Local Taxes introduced as local taxes: real property tax, dog tax, tax on use of public areas, accommodation tax, vending machines tax, non-winning gaming machines tax, tax on use of public areas, tax on enter and stay of motor vehicles in historical parts of towns, nuclear facility tax (as taxes administered by municipalities), and motor vehicle tax (the only tax administered by higher territorial units). It actually adopted the former regulation of local charges, property tax, and road tax set by the mentioned statutes, naturally with certain adjustments and with one difference, which was change of character of the taxes. Formerly, the mentioned taxes used to be state taxes but their beneficiary was local self-government. The real property tax was 
administered by municipalities. Actual imposition of tax was enacted by the mentioned statute and the municipalities were entitled to grant reliefs through their generally binding regulations, though. Regulation itself was significantly similar to the current one ${ }^{9}$ comprising the tax on lands, tax on structures and tax on flats and non-residential premises. Currently, i.e. since 1 January 2015, the tax on motor vehicles is regulated in a separate statute - act no. 361/2014 Coll. on motor vehicles tax and on change and amendment of certain laws and again as a state tax. Local taxes are fully administered by local self-government - municipalities, who are also their beneficiaries. The taxes are imposed by municipalities themselves by means of generally binding regulations. Within these, municipalities are allowed to adjust tax rates, value of building lands, floor surcharge, additional reliefs, instalments, reporting duties $\&$ data to be reported to tax administrator, etc., which enables them to regulate the local taxation according to their local needs.

Among local taxes, the most important own tax resource is the real property tax. Property tax is three tier and is levied on (a) lands, (b) buildings, and (c) flats and non-residential premises. The division among these separate objects is necessary due to lack of application of principle of superficies solo cedit in Slovak legal order which results into situations that constructions built on particular plot of land and that plot may be owned by different persons. The tax is predominantly based on the area of property and the use of variety of tax rates relating to differences between types of properties, the purpose of their use and location, which actually serves as adjustment of predominantly area-based type of real property tax. Primary tax rates are stipulated by the Act on Local Taxes and these are: $0.25 \%$ per annum regarding the land tax, 0.033 EUR per each commenced square meter of the built-up area per annum regarding the tax on constructions, and 0.033 EUR per each commenced square meter of the flat area per annum regarding the flats/non-residential premises tax. Municipalities may set different tax rates in the generally binding regulation, application of which is a common practice. Moreover, they are allowed to determine different rates for different types of lands, constructions, flats, and non-residential premises and to take into consideration also the purpose of their use and the location - e.g. in relation to the city centre, cadastral areas, other zones, or

9 With slight differences, though, e.g. the basic statutory tax rates were multiplied by coefficient (1.0 to 4.0 ) according to size of municipality based on the number of inhabitants and administrative importance of particular town (7 levels) and separately for the capital city of Bratislava (coefficient 4.5) (see more e.g. art. 6 par. 4 of the act no. 317/1992 Coll.). 
otherwise $^{10}$. This diversification of tax rates (together with establishment of a floor surcharge - for multi-storey buildings $)^{11}$ can be fully adjusted to local circumstances and used as a tool of local tax policy of each municipality since the Act on Local Taxes gives the municipalities full powers to determine "different tax rates within the area of municipality or parts of it". Since the adoption of the Act on Local Taxes, when municipalities had no limitation regarding the mentioned power of determination of tax rates, the legislator has adopted several amendments to the Act on Local Taxes to limit this power. Currently, the mentioned differently determined rates shall meet two tier limits: Firstly, the limit regarding determination of zones, i.e. individual parts of area of municipality where different tax rates are to be applicable, is stipulated by the Act on Local Taxes in art. 17a which states that individual part of municipality is a geographically compact part of municipality comprising minimum of $5 \%$ of property tax taxpayers of the municipality and is established within generally binding regulations of the municipality. Individual part of the municipality may be formed by a street, neighbouring streets or neighbouring plots of land. Secondly, the municipalities became limited as regards the height of tax rates as follows: (i) highest rates stated in the generally binding regulation must not exceed the basic statutory rate more than 5 times in case of arable land, hop gardens, vineyards, orchards, permanent grassland; (ii) highest rates stated in the generally binding regulation must not exceed the basic statutory rate more than 10 times in case of forest lands with economic woods, ponds with fish farming and other economic used water areas; (iii) the rate regarding the land tax on lands functionally connected to nuclear facility must not exceed the rate stated by the Act more than 100 times; (iv) highest rates stated in the generally binding regulation must not exceed the lowest rates stated in the same regulation more than 5 times as to the land tax on other types of lands and 10 times as to the constructions tax, tax on flats and non-residential premises. The rest of the local taxes are rather of less importance as regards the effect on budget of municipalities.

10 In larger towns, it is standard to set 2-4 zones usually based on traditional division to city centre, wider centre and suburbs, but it depends on each municipality what kind of division, if any, chooses.

11 N. Antošová, Quantitative parameters and their concepts as a way of comparing technical and economical indicators of buildings, [in:] "Nehnutel'nosti a bývanie", 2013, No. 1, pp. 26-38. 
As regards local charges, Slovak legislation recognises two of them, being the first, the local charge for municipal waste and small construction waste (hereinafter only "charge for municipal waste") and the second, the local charge for development (hereinafter only "charge for development"). The charge for municipal waste is regulated by the Act on Local Taxes and until adoption of the charge for development, it used to be the only local charge applicable. The charge for development as a new tool of local funding is regulated by the act no. 447/2015 Coll. on local charge for development and on amendment of certain laws which was adopted on 20 November 2015 and will be effective from 1 November 2016. Currently, the charge for municipal waste is paid for municipal waste and minor construction waste arising in the territory of municipality, except for electronic equipment, batteries and accumulators formerly used by natural persons, and biodegradable kitchen and restaurant waste. With effect from 1 July $2016^{12}$, this charged will be paid for management of unsorted municipal waste; management of biodegradable municipal waste; separate collection of municipal waste components not covered by the producer's extended responsibility; costs caused by inconsistent sorting of separately collected fractions of municipal waste covered by producer's extended responsibility; and costs exceeding the usual amount of costs pursuant to cause by disobedience of measures ordered to achieve a more efficient functioning of separate collection of waste ${ }^{13}$, which means broadening of the scope of the charge. The rate is (a) from EUR 0.0033 to 0.0531 per one liter of municipal waste and minor construction waste, or from EUR 0.0066 to 0.1659 per one kilogram of municipal waste and minor construction waste; (b) from EUR 0.0066 to 0.1095 per person per calendar day; (c) from EUR 0.015 to 0.078 per kilogram of minor construction waste free of pollutants. The mechanism of computing the actual amount of the charge depends on whether the municipality uses the collection based on amount of waste or a flat collection - per person and length of the time that person is considered as the payer of the charge (residency in the municipality or usage of a property within municipality). The charge for development will be levied upon a construction on land ${ }^{14}$ within the territory of municipality

12 Amendment was made by act no. 79/2015 Coll. on wastes and on change and amendment of certain laws.

13 Pursuant to art. 59 para. 7 and 8 of act no. 79/2015 Coll., on wastes and on change and amendment of certain laws.

14 Except for minor constructions, extensions and outbuildings up to 25 square meters of floor area, emergency construction works, family houses with a floor area up to 150 square 
for which a valid building permission is issued. The rates can be stipulated by the municipality's GBO within the range from EUR 10 to 35 and different categories of constructions can be charged with various rates. The base of the charge is the area of aboveground part of floor area of the construction which is, in this specific case, comprising the floor area of all aboveground rooms, not only one specific aboveground level of construction as such. The Revenue from the charge for development can only be used for specific purposes, i.e. to cover capital expenditures related to constructions (including the settlement of land) to be used as childcare facilities; facilities providing social, sporting and cultural services; social housing; school equipment and devices for the practical training; medical equipment; publicly accessible park or adjustment of public green; local roads, parking areas and technical infrastructure.

\section{Application problems of local taxes - where is the line between authonomy and willfulness?}

Autonomy of tax administrators of real property tax is undoubtedly their legitimate right and on the background of all the facts and assumptions we do believe that it is a necessary element of their existence and financial independence. Practical life can, however, bring situations where it is very difficult to draw a border and to recognise what is be considered as a manifestation of their autonomy and what rather the wilfulness of the tax authorities in determining the rate of real property tax. For rendered scenario, we decided to highlight one particular case on which the ultimate decision was delivered by the Supreme Court of the Slovak Republic (case no. 8Sžf/22/2010).

The taxpayer rented arable land with an area of 1373491 square meters and a permanent grassland in an area of 617965 square meters. By generally binding regulation, the tax administrator, i.e. the municipality, determined the tax rate on these types of lands in the amount 12-times higher than the lowest annual rate on land tax set by the tax administrator. On such basis, he assessed the tax in total amount of EUR 17 486.31. A taxpayer disagreed with the tax assessment and appealed against the decision of tax administrator,

meters, constructions used for social housing or childcare, built-in garage and parking spaces within an existing building, medical facilities, serving to kindergartens or schools, social service facilities, practice of religion, protection of the state, museums, galleries, libraries and cultural centres. 
subsequently with the Tax Directorate and finally with a District court. He argued that a twelve-fold increase of the tax on arable land and permanent grassland had solely purposeful character directed against him because the land tax is higher than the total value of the property and if he paid the tax, it would have meant the termination of his business resulting into job losses in the region. The taxpayer also argued that this type of tax is applied solely and only on his company in the cadastral territory of the municipality. The taxpayer further stated that manners and actions by the elected representatives of the municipality should be in accordance with good morals, hence, from the taxpayer's point of view, such manners should be considered as abuse of law. The tax administrator, the Tax Directorate and then also the District court, non-dependent on each other, confirmed the challenged decision. The Slovak Supreme Court - as the appellate court - reviewed the contested judgment of the District court without a hearing and confirmed it as factually accurate. The appellate court disregarded the applicant's argument of the lack of fact-finding and violation of law, vexatious exercise of rights, contravention of the good morals and abuse of the authorities of the municipality.

In this context, we consider important to emphasize that the taxpayers of real estate tax who are legal persons are not entitled to be granted a reduction or a relief on tax, only on tax penalty, as opposed to those who are natural persons ${ }^{15}$. Similarly, it is not possible regarding the state taxes under the Slovak Tax Procedure Code $^{16}$, either. Taxpayers, legal persons mainly, appeal in similar cases against tax authorities or bring the actions to the court. Settled case-law in such cases speaks in favour of the tax authorities, though.

The Constitutional Court of Slovak Republic was due to cumulating of cases similar to one we indicated above required to deal with the question of the constitutionality of selected provisions of the Act on Local Taxes. A group of Parliament Members asked it to express its opinion on the regulation of the maximum rate of local taxes, especially in relation to the property tax. The Constitutional Court of Slovak Republic delivered a preliminary ruling under

15 Natural persons may be granted a relief from tax or tax penalty in case that enforcement of tax would lead to serious endangerment of nourishment of the taxpayer or persons dependant on him. Legal persons may be granted only a relief on tax penalty in case that they prove that its payment would lead to business closure and revenue from the liquidation would probably be lower than the levied penalty.

16 Act no. 563/2009 Coll., on administration of taxes (Tax Procedure Code) and on change and amendment of certain laws, as amended. 
art. 125 of the Constitution in the matter of deciding on the conformity of three provisions of Act on Local Taxes. Imperfection of Act on Local Taxes and its unconstitutional character was asserted by the group of Parliament Members in relation to the following provisions of Act on Local Taxes concerning the real property tax:

- Art. 8 para. 2 second and third sentence: By a generally binding regulation, the tax administrator may, in view of the local circumstances in a municipality or part thereof, set different tax rates for individual types of land according to article 6 paragraph 1 or for individual cadastral areas. The land tax rate thus established shall not exceed 5 times the lowest annual land tax rate established by the tax administrator in a generally binding regulation. The annual tax rate for a land functionally connected to the structure of a nuclear facility shall not exceed 100 times the annual rate referred to in section 6 subsection 1 .

- Art. 12 para. 2 second and the third sentence: By a generally binding regulation, the tax administrator may, in view of the local circumstances in a municipality or part thereof or in a particular cadastral area, set different tax rates for individual types of buildings according to article 10 paragraph 1. The thus established rate of the tax on buildings referred to in article 10 paragraph 1 shall not exceed 10 times the lowest annual rate of the tax on buildings established by the tax administrator in a generally binding regulation for buildings referred to in article 10 paragraph 1.

- Art. 17 para. 2 letter 1): By a generally binding regulation issued in view of the local circumstances in a municipality or a specific part thereof, the tax administrator may provide for land tax reduction or exemption in respect of: land, except for land situated in the built-up areas of municipalities, used for agricultural production by self-employed farmers conducted as their main activity.

According to the group of Parliament Members, the imperfection and unconstitutional character of mentioned provisions consists in the fact that the provisions allow municipalities to set different tax rates for individual types of land and for individual types of buildings, and reduce or exempt from tax certain type of land. As one of the most problematic aspects seems to be the fact that at the same time no provision allows the municipality to reduce the tax or provide any relief on tax on land, other than land situated in the built-up areas of municipalities, used for agricultural production by self-employed farmers 
conducted as their main activity. This formulation could be considered as discriminatory and disadvantaging. Members of the Parliament identified another imperfection in connection with the absence of definition of the maximum annual rate of those taxes. Complainants argued that unconstitutional character of the mentioned provisions of the Act on Local Taxes leads to serious practical problems, especially the distortions of legal environment, restrictions on freedom of establishment and the fundamental rights and freedoms (in particular legal and natural persons carrying on business in the field of agriculture and agricultural production) in such a strong way that, in the opinion of the complainants, it is absolutely unacceptable. The group of Parliament Members in its application further argued that the application level of the Act on local taxes which is reflected in the relevant generally binding regulations of municipalities, does not reflect the needs of taxpayers and causes conscious and/or unconscious competitive favouritism based on unilateral and often the ultimate act of the municipality which the taxpayers are obliged to respect without factual possibility to defend themselves against such practice of the tax authorities. The aim of adopted legislation was to make the tax administration on the municipal level more rationalised and thus create conditions for real progress of municipalities not to induce conditions for the municipalities as tax administrators to abuse their powers in order to fill their budgets. Such an activity leads to the reduction in the competitiveness of taxpayers ${ }^{17}$ who use for their production and for their businesses real estates (buildings, land) - within both the micro-regions of Slovak Republic, and also the country as whole - in comparison with the neighbouring countries.

The Constitutional Court of the Slovak Republic dismissed the application $^{18}$. It considered to be crucial that the whole proposal of the Group of Parliament Members was essentially based on generalized consideration that municipalities abuse their relatively generous law-making powers that are defined in the Act on Local Taxes within the framework of deciding on particular specifics of each local tax. The Court concluded that in case of abuse of law

17 K. Červená, Podpora rozvoja podnikania malých a stredných podnikatel'ských subjektov $v$ SR, [in:] Stretnutie finančných právnikov, Bratislava 2007, pp. 31-40.

18 Finding of the Constitutional Court of Slovak Republic of 22 January 2013, case PL. ÚS 5/2012. For more details of the case see also: K. Prievozníková, I. Vojníková, Autonómia vs. svojvôl'a spróvcu dane pri stanovení sadzieb z nehnutelnosti, [in:] Dny próva 2014 Days of Law 2014: Zneužití próva a svévole při veřejné finanční činnosti, část VIII, Brno 2015, pp. 359-374. 
there are legal mechanisms providing for protection, such as the review of unconstitutionality or unlawfulness of generally binding regulations of municipalities and higher territorial units, which falls within the competence of the Constitutional Court, and there are also other legal tools to protect the rights and freedoms or the legitimate interests of individual groups of taxpayers, e.g. protest of prosecutor and jurisdiction of general courts. The Constitutional Court concluded that the contested provisions of the Act on Local Taxes are not in conflict with any of the provisions of the Constitution which was identified by the Group of Parliament Members. Under these circumstances, according to the opinion of the Constitutional Court, other conclusions would constitute a disproportionate interference with the autonomy of municipalities guaranteed by the Constitution and the constitutional right to exercise self-government.

Primarily, the issues of taxes and fees fall within the realm of so-called "political issues" in the assessment of which the Constitutional Court of Slovak Republic and other constitutional courts would generally be more hesitant and respect the high degree of autonomy of the Parliament. For this reason, the Constitutional Court should therefore in search of protection of the constitutionality intervene in the sphere of taxes and fees by its case law only in exceptional and duly justified cases. This might be particularly in case of breach of principle of legality during the process of adoption of generally binding regulation, the imposition of the tax would not pursue any legitimate aim and had no reasonable basis or when levying of the tax would mean a massive tax burden for taxpayers, or if the means of imposition of taxes would be an expression of apparent arbitrary violation of the constitutional principle of equality or other constitutional principles. ${ }^{19}$ The second reason is that the Constitution itself supports the right of municipalities and higher territorial units to perform their self-government, meaning the guaranty of a high autonomy in

19 In the case law of The European Court for Human Rights, the issue of taxes, or rather determining of tax liability, is perceived primarily in terms of the right to peaceful enjoyment of possessions guaranteed by Art. 1 of Protocol to the Convention for the Protection of Human Rights and Fundamental Freedoms. Generally, the interference with the right to peaceful enjoyment of possessions could be excused if it occurred legally (following the principle of legality) and if it pursues a legitimate objective in the form of public (general) interest and insofar as a fair balance between the interests of the protection of individual property and broader societal interests was achieved. This also means that an individual cannot - referring to the public or general interest - carry excessive or unreasonable (tax) burden (Wasa Liv Ömsesidigt, Försäkringsbolaget Valands Pensionsstiftelse and others against Sweden, Application No. 13013/87, Decision, 14. 12. 1998, DR 58, p. 186). 
deciding on local issues, including decisions on local taxes and fees. In such circumstances, it is quite inconceivable for the legislator to limit the autonomy of municipalities and higher territorial units in the sphere which should, from the large part, secure this autonomy.

\section{Challenges \& conclusions}

In the sphere of public finances in Slovak Republic, the year 2004 represents an important milestone since the model of so-called fiscal decentralization was implemented into our legal framework. The aim of fiscal decentralization was to establish legal and financial tools indented for municipalities to be capable of accomplishment of their tasks imposed by legal acts, including education, social, and culture tasks, as well. ${ }^{20}$ As one of the most important tools of fiscal decentralization may be considered an Act on Local Taxes ${ }^{21}$. Under the mentioned Act, municipalities and higher territorial units ${ }^{22}$ were allowed to impose local taxes ${ }^{23}$ and local fees by their generally binding regulations (effective not earlier than on 1 January 2005) which actually represented the first truly

20 Compare V. Babčák, Fiskálna decentralizácia a reforma miestnych daní, [in:] Aktuálne otázky finančného práva a daňového práva v Českej republike a na Slovensku, Danišovce 2004, p. 13.

21 Compare M. Štrkolec, Daň z nehnutelnosti a jej vyrubovanie a platenie v rámci daňového konania, [in:] Stretnutie finančných právnikov, Bratislava 2007, p. 163.

22 The higher territorial units were entitled to impose the tax of motor vehicles. Act No. 361/2014 Coll., on Motor Vehicle Tax and on Amendment to and Supplementing of Certain Acts entered into force on 1 January 2015 and implemented many changes in this area. The Act was adopted due to changes in fiscal system, as the motor vehicle tax is no longer the revenue of higher territorial units, but of the state budget instead. The amendment introduces fixed tax rates for the whole territory of the Slovak Republic, although, the annual tax rate is to be adjusted, firstly, according to the number of months that have elapsed since the first month of registration of the vehicle in the SR, and eventually secondly, reduced by 50 percent depending on the type of vehicle drive. This additional reduction applies to hybrid engine and hybrid electric vehicles, vehicles running on compressed or liquefied natural gas, and hydrogen-powered vehicles. (See also: M. Bujňáková et al., Dane a ich právna úprava v Slovenskej republike v kontexte daňovej politiky EÚ, Univerzita Pavla Jozefa Šafárika v Košiciach, Košice 2015, 408 p.)

23 The act established a) real estate tax, b) dog tax, c) tax on the use of public areas, d) accommodation tax, e) tax on vending machines, f) tax on non-winning gaming machines, g) tax on the entry and stay of motor vehicles in historical parts of towns, h) nuclear facility tax. 
own resource of their funding, even though such a scheme of own - local taxes was envisaged by the Constitution since 1992. Following the Constitution and the actual goal of fiscal decentralisation, i.e. to create an independent self-government that is capable of funding its needs and execute its policy by own resources, it is obvious that the funds obtained within the own resources should prevail. Even within the above defined group of own resources as set by the Act on Fiscal Rules, we can clearly identify that some of the above resource (e.g. shared taxes) should not be declared to be own resource, since this source depends on the personal income tax and is divided among municipalities and higher territorial units, in the amounts set by the law upon decision of the state, not the local self-government. This means that we have to distinguish the own resources in terms of the mentioned statute and actual own resources of local self-government as those acquired by local self-government itself and which may be called as genuine local resources of funding.

The ideal situation after ten years from the introduction of the model of fiscal decentralization would be that we could declare that all criteria mentioned under the Charter were met. The last point, however, even with a great deal of optimism in our opinion, cannot be regarded as fulfilled, and if at all, only with reservations. The phenomenon we have been observing since the creation of independent Slovak Republic is the lack of ability of municipalities to acquire true own resources for funding of their needs. Considering the exact "numbers" regarding the above mentioned revenues, in 2014, transfer of shared taxes - personal income tax to the municipalities represented EUR 1301088 000, grants and transfers (largely to cover performance of transferred state administration) of EUR 1198298 000, non-tax revenues amounted to EUR 634656 000, local taxes revenues accounted for EUR 496622000 (from which EUR 320453000 stands for real property tax and the rest comprises the other local taxes and, mainly, local charge for municipal waste), and EUR 398467000 was created by other income (loans, transfer of funds from other monetary funds, transfer of funds from previous budgetary year, etc. $)^{24}$. Looking at the ratio of particular municipality's budgetary revenues, it clearly shows that genuine own, i.e. local, sources of funding are definitely insufficient. ${ }^{25}$ Beside search for better tax

24 Data acquired from: Ministry of Finance of Slovak Republic: Budget of public administration for years 2016-2018. Available at the Internet: http://www.finance.gov.sk/Default. aspx?CatID=10249.

25 A. Románová, Miestne dane ako zdroj príjmov rozpocttov územnej samosprávy, [in:] Verejné financie Slovenskej republiky - vybrané aspekty a tendencie vývoja, Košice 2011, p. 
revenues, also the group of non-tax revenues should be considered as an issue to improve and develop. This group (comprising revenues from own business activities, use of municipal movable and immovable property and its disposal, administrative and other fees and charges for specific services) is definitely a sphere where abilities and creativity of particular municipality can be shown. As we see, the revenue from local taxes and charges is similar to that gained from non-tax revenue, which is a significant amount.

We mentioned above two major amendments to legislation that are already valid and will take effect within the current year, i.e. the new charge on development and amendment of charge on municipal waste. The background or the main reason of the change is obvious and it is nothing else than fiscal interest, nevertheless, it is the matter of future whether it meets the intended goal. Ever since the introduction of fiscal decentralisation, local self-government keeps fighting with the inadequate funding of their needs as regards covering the independent functioning and securing their own self-governing tasks. This struggle for balance in relation between competences and resources definitely needs a more efficient solution then a sole almost 20-years lasting debate on how to solve the problem. Beside the changes regarding the regulation of the local charges, a strong issue is a fundamental change of system of taxation of real property. In recent years, the Government of Slovak Republic (perhaps also due to pressure of the $\mathrm{EU}^{26}$ ) has been presenting an idea of fundamental reform of real property tax as regards the base of taxation. The eventual proposal should move from area based system to ad valorem system. An important signal is that this task has got to the Government Manifesto for years 2016-202027, nevertheless, it has been mentioned in National programmes of reforms in Slovak Republic for last few years without any legislative results. In our view, the crucial reason for the reform is the equity issue due continuous limitation of powers of municipalities to determine tax rates according to reduce the differences form from the statutory rates and differential rates within particular

63-68.

26 See Council Recommendation of 8 July 2014 on Slovakia's 2014 national reform programme and delivering a Council opinion on the Stability Programme of Slovakia, 2014 (2014/C 247/23).

27 The government in cooperation with the Association of Towns and Municipalities of Slovakia will create the technical prerequisites for change of the system of taxation of real estate towards the determination of the tax base by the estate's value in order to increase tax fairness and efficiency in the sphere of local taxation. Government Manifesto for years 2016-2020, p. 21. 
municipality. In favour of this inconsistency speaks also unofficial information on only a slight increase of presumed revenue that should be achieved by the change of current system. Nevertheless, also the equity matter is questionable since too many practical problems are still visible (mainly due to in complexity of database and state of development of real estate market). Hence, the accurate data must be acquired at first place, to achieve the goal of tax fairness that should be brought by the new system of taxation. From the already published documents of the Government, it seems that the reform should firstly aim at residential properties which might be the easiest start, due to availability of transactions data, however, from the budgetary view, the commercial properties are those of higher value. The imbalance of real estate market within various regions of Slovakia is a problem that needs to be solved, as well. An important issue that should not be underestimated is tackling first the aspects of local administration as regards the problems with enforcement of local charges, but room is also visible regarding the overall debts on local taxes in case of some municipalities that still have not been collected. In our view, an improvement of state of the art, until time for a complex reform is adequate, might be achieved in an acceptable way by further adjustment of current regulation by other coefficients along with the existing ones (type of property, purpose of use, and location). The variability of tax rates, however, may be and should be used wisely, though. Even though the local taxes are ones that may be easily adjusted by municipalities, a direct consequence of the exclusive autonomy of municipalities as tax authorities can also be the creation of a huge disproportionality of the final tax liabilities of comparable subjects - not only between regions but also in different parts of the municipality, as be pointed out above. In such cases we can barely talk about the principle of fair taxation. Autonomous determination of tax rates may also bring situations where particular entities in an individual part of a municipality are burdened by a disproportionately high tax liability. If the assessed tax is disproportionately high, legal persons are (as compared to the natural persons) disadvantaged because there is no effective possibility to granted reduction of the assessed tax. We are of the opinion that described system should be denoted as imperfect. This is also the reason for permanent discussions about fairer adjustment of taxation of real estate, for example via mentioned ad valorem system of taxation of real estate ${ }^{28}$. We believe

28 M. Bujňáková, A. Románová, Zamyslenie sa nad ideou zavedenia zdaňovania nehnutel'nosti na princípe trhovej hodnoty, [in:] Právo-Obchod-Ekonomika, Košice 2014, pp. 61-76. 
that, as the Constitutional Court of the Slovak Republic declared, local tax authorities have a legitimate right to decide on such matters autonomously ${ }^{29}$. And yet, based on the experience with the potential practical problems and in the context of ensuring legal certainty of taxpayers, we believe that it would be worth considering the introduction of a mechanism that could correct the excessive interference in the sphere of property taxation, e.g. in cases when the amount of the levied tax is comparable with the total value of real estate. Such situations are not desirable and contravene not only the principle of fair taxation, but even the rules of logic. Remedies for alleviation of hardship of law in individual cases for legal entities such as those applicable to natural persons may be considered, as well.

To summarize, despite the existence of a complex legal framework that shall ensure sufficient powers together with financial coverage of local self-government's tasks, in Slovakia, the representatives of municipalities have to face to many serious financial, political, and legal problems. Some of the most significant problematic issues of present days such as insufficient funding with high dependency on state budget, discussion about fairer model of taxation (ad valorem taxation of real estates) and misconduct (bordering to misuse) of their self-governing powers calling for setting of optimal limits of local self-government's autonomy were analysed in this chapter, however, there is still a longer list of current problems, such as permanent strong interference of state power with the local self-government, high quotient of mandatory expenditures in local self-governments' budgets, high quotient of expenditures on salaries of municipality representatives and expenditures on existence and functioning of municipal offices, consolidation of public finance and reducing of public debt, that should be comprehensively considered. Therefore, the envisaged reform of property taxation might also provide a room for improving of at least any of the above mentioned problems with which the municipalities (and their taxpayers) have been fighting for a long time.

\section{Literature}

1. Antošová N., Quantitative parameters and their concepts as a way of comparing technical and economical indicators of buildings, [in:] "Nehnutel'nosti a bývanie" 2013, no. 1, pp. 26-38.

29 M. Vernarský, Obec ako subjekt oprávnený ukladat' miestne dane, [in:] Územná samospráva ako forma verejnej moci, Košice 2012, pp. 155-164. 
2. Babčák V. et al., Finančné právo na Slovensku a v Európskej únii, Eurokódex, Bratislava 2012.

3. Babčák V., Fiskálna decentralizácia a reforma miestnych daní, [in:] Aktuálne otázky finančného práva a daňového práva v Českej republike a na Slovensku, Košice 2004.

4. Bujňáková M. et al., Dane a ich právna úprava v Slovenskej republike v kontexte daňovej politiky EÚ, Univerzita Pavla Jozefa Šafárika v Košiciach, Košice 2015.

5. Bujňáková M., Románová A., Zamyslenie sa nad ideou zavedenia zdaňovania nehnutelností na princípe trhovej hodnoty, [in:] Právo, obchod, ekonomika IV: zborník vedeckých prác, Košice 2014, pp. 61-75.

6. Červená K., Podpora rozvoja podnikania malých a stredných podnikatel'ských subjektov v SR, [in:] Stretnutie finančných právnikov, Bratislava 2007.

7. Kicová A., Štrkolec M., Vzjomné finančno-právne vzt’ahy jednotiek územnej, [in:] Finanse samorzadu terytorialnego, Random 2012.

8. Prievozníková K., Vojníková I., Autonómia vs. svojvôl’a správcu dane pri stanovení sadzieb z nehnutelnosti. [in:] Dny práva 2014 - Days of Law 2014: Zneužití práva a svévole při veřejné finanční činnosti, část VIII, Brno 2015, pp. 359-374.

9. Prievozníková K., Vojníková I., Východiská a prognózy miestnych daní, [in:] Financie, účtovníctvo, dane 2014 so zameraním na súčasné problémy II, Košice 2014, pp. 58-63.

10. Románová A., Miestne dane ako zdroj príjmov rozpočtov územnej samosprávy, [in:] Verejné financie Slovenskej republiky - vybrané aspekty a tendencie vývoja, Košice 2011, p. 63-68.

11. Štrkolec M., Daň z nehnutel’nosti a jej vyrubovanie a platenie v rámci daňového konania, [in:] Stretnutie finančných právnikov, Bratislava 2007.

12. Vernarský M., Obec ako subjekt oprávnený ukladat' miestne dane, [in:] Územná samospráva ako forma verejnej moci, Košice 2012, pp. 155-164.

Anna Románová, Ivana Forraiová Pavol Jozef Šafárik University in Košice 